\title{
PEMBERDAYAAN MASYARAKAT MELALUI PENGOLAHAN SAMPAH ORGANIK DI DESA TEMPURSARI KECAMATAN TEMPURSARI, KABUPATEN LUMAJANG, JAWA TIMUR
}

\author{
Elferida Sormin ${ }^{1}$, Marina Silalahi ${ }^{2}$, Bambang Widodo ${ }^{3}$, Susilo ${ }^{4}$ \\ Universitas Kristen Indonesia, Jakarta, Indonesia ${ }^{1,2,3,4}$ \\ elferidasormin@yahoo.com ; marina_biouki@yahoo.com; bambang.widodo@uki.ac.id ; \\ susilointhehoy@gmail.com
}

\begin{abstract}
Abstrak
Kegiatan pengabdian kepada masyarakat ini dilakukan melalui bentuk kegiatan sosialisasi dan pelatihan tentang pengolahan sampah di Desa Tempursari, Kecamatan Tempursari, Kabupaten Lumajang, Jawa Timur pada tanggal 12-17 Juli 2017. Permasalahan sampah menjadi permasalahan yang belakangan sangat banyak dikeluhkan oleh masyarakat secara khusus di desa Tempursari. Kerjasama yang solid antara semua stakeholder diharapkan dalam penanganan dan pemecahan permasalahan sampah ini, seperti yang sudah dilakukan oleh masyarakat Desa Tempursari dengan kehadiran Gereja Kristen Jawa Wetan (GKJW) yang menjadi fasilitator dalam penanganan sampah di desa Tempursari. Dalam rangka mengembangkan program yang sudah disusun dan akan dijalankan, GKJW bekersama dengan Universitas Kristen Indonesia Jakarta dalam beberapa hal terkait pengolahan sampah tersebut, di antaranya mensosialisasikan pemahaman tentang sampah (jenis dan dan dampak yang ditimbulkan), bagaimana mengolah sampah sesuai dengan jenisnya dan membantu mengoperasikan mesin pencacah sampah plastik dan sampah organik lainnya. Hasil dari kegiatan pengabdian kepada masyarakat ini dinilai memberikan dampak positif, di mana mesin pencacah yang tadinya sudah lama tidak berfungsi menjadi beroperasi dengan operator yang yang sudah mahir atau fasih, masyarakat mampu memilah sampah dimulai dari tia-tiap rumah tangga sebelum selanjutnya diserahkan ke tim pengolah yang sudah ditunjuk oleh gereja. Akhirnya setelah kegiatan pengabdian kepada masyarakat bersama dengan GKJW Tempursari, maka program pelayanan masyarakat melalui pengolahan sampah oleh GKJW Tempursari mulai berjalan lancar.
\end{abstract}

Kata Kunci: sampah organik, mesin pencacah

\begin{abstract}
The community service activities were carried out through the form of socialization and training activities on waste management in Tempursari Village, Tempursari District, Lumajang Regency, East Java. The problem of garbage has become a very recent problem that is very much complained by the community specifically in the village of Tempursari. Solid cooperation between all stakeholders is expected in handling and solving these waste problems, as has been done by the people of Desa Tempursari with the presence of the Gereja Kristen Jawa Wetan (GKJW) who became a facilitator in handling waste in the village of Tempursari. In order to develop a program that has been compiled and will be implemented, GKJW cooperates with the Universitas Kristen Indonesia Jakarta in several matters related to waste management, including socializing understanding of waste (types and impacts), how to process waste according to its type and helping operate plastic waste chopping machines and other organic waste. The results of community service activities are considered to have a positive impact, where the enumerating machines that have not been functioning for a long time become operational with operators who are already proficient or
\end{abstract}


fluent, the community is able to sort waste starting from each household before being submitted to the processing team who has been appointed by the church. Finally after the community service activities together with GKJW Tempursari, the community service program through processing waste by GKJW Tempursari began to run smoothly.

Keywords: organic waste, chopping machine

\section{PENDAHULUAN}

\section{Latar Belakang}

Kecamatan Tempursari merupakan salah satu kecamatan yang terdapat di Kabupaten Lumajang, Provinsi Jawa Timur. Kecamatan ini memiliki tujuh desa dengan jumlah total penduduk sampai tahun 2018 sekitar 32.425 jiwa, di mana dari tujuh desa tersebut Desa Tempursari merupakan desa dengan kepadatan penduduk tertinggi yaitu $335 \mathrm{~km} / \mathrm{jiwa}$ dibandingkan enam desa lainnya. https://lumajangkab.go.id/profil/kectmpsr.p hp.,2019.

Desa Tempursari merupakan desa dengan tingkat kesuburan yang terbagi ke dalam dua kategori daerah yaitu daerah subur dan daerah sedang. Keberagaman suku, agama dan bahasa juga terdapat di sana, sebagai contoh di Desa Tempursari penduduknya ada yang menganut Agama Islam, Hindu dan Kristen. Namun keberagaman tersebut justru dibungkus dengan kebersamaan dan kesatuan masyarakat desa Tempursari. Kesehatian dan semangat kerjasama gotong royong menjadi hal yang utama bagi masyarakat desa Tempursari. Salah satu contoh nyata adalah ketika pada saat perayaan harihari besar keagamaan, semua masyarakat saling bersilaturahmi dan saling mengunjungi.

Selain itu yang menjadi contoh kesatuan dan kebersamaan masyarakat desa Tempursari adalah kehadiran Gereja Kristen Jawa Wetan (GKJW) di desa Tempursari yang menjadi tempat kumpul anak-anak muda, dikarenakan gereja tersebut menyediakan beberapa fasilitas dan program pengembangan masyarakat, seperti hotspot wifi, sarana olahraga, bahkan yang sangat menarik adalah program bank sampah yang dikelola oleh GKJW dengan sistem terbuka untuk umum.

Kegiatan pengumpulan sampah ini dilakukan dengan mempersilahkan masyarakat mengantar sampah baik berupa sampah sisa olahan dapur (sisa makanan, limbah sayuran, dan lainnya) maupun sampah plastik, yang selanjutnya dikumpulkan di lokasi yang sudah disediakan GKJW, bahkan pihak GKJW juga sudah menyediakan alat transportasi pengangkut sampah dari rumah-rumah penduduk. Sebagai tanda bukti sudah mengantar atau menyetor sampah, masyarakat memiliki tanda bukti berupa buku tabungan sampah. 
Kegiatan tersebut merupakan kegiatan rutin yang dilakukan oleh masyarakat desa Tempursari dengan jadwal pengantaran sampah sebagaimana sudah ditentukan. Sampah yang sudah terkumpul, selanjutnya akan diolah dan dikonversi menjadi beberapa bahan yang memiliki daya guna sosial dan ekonomi bagi masyarakat desa Tempursari. Sebagai contoh sampah sisa olahan dapur dapat diolah menjadi pupuk organik cair ataupun padat, sedangkan sampah plastik dapat diolah menjadi biji plastik yang kemudian dapat dijual dengan harga yang lebih tinggi. Direncanakan hasil penjualan akan dikembalikan kepada penduduk sesuai dengan jumlah setoran sampah masing-masing.

Sampah yang dalam bahasa inggris dinyatakan waste merupakan bahan yang terbuang atau dibuang dari sumber hasil aktivitas manusia ataupun alam yang belum memiliki nilai ekonomi yang memiliki bentuk dalam fase materi padat, cair dan gas.(Risman Z, 2018)

Pengelolaan sampah (UU-18/2008): Adalah kegiatan yang sistematis, menyeluruh, dan berkesinambungan yang meliputi pengurangan dan penanganan sampah. Catatan: pengertian pengelolaan bukan hanya menyangkut aspek teknis, tetapi mencakup juga aspek non teknis, seperti bagaimana mengorganisir, bagaimana membiayai dan bagaimana melibatkan masyarakat penghasil limbah agar ikut berpartisipasi secara aktif atau pasif dalam aktivitas penanganan tersebut. Adapun yang menjadi penghasil sampah menurut UU nomor 18 tahun 2008 adalah setiap orang atau kelompok orang atau badan hukum yang menghasilkan timbulan sampah. Sampah yang diatur dalam UU-18/2008 yakni sampah rumah tangga, sampah sejenis sampah rumah tangga. Sampah spesifik sampah rumah tangga yaitu sampah yang berasal dari kegiatan sehari-hari dalam rumah tangga, tidak termasuk tinja dan sampah spesifik. (Damanhuri, E., 2010).

Seiring dengan berjalannya waktu, antusiasme masyarakat desa Tempursari sangat tinggi mengakibatkan jumlah sampah yang terkumpul sangat banyak, selain itu pengurus atau tim yang bertanggungjawab mengalami kesulitan dan kendala dalam hal pengolahan di mana sampah sisa rumah tangga/dapur belum berhasil diolah menjadi pupuk organik (cair/padat), terdapat satu mesin pencacah sampah plastik dan satu mesin pencacah sampah limbah rumah tangga yang merupakan sumbangan dari jemaat gereja, namun hingga bulan Juni tahun 2017, mesin tersebut belum berhasil dioperasikan.

Beberapa kendala di atas menimbulkan permasalahan baru akibat menumpuknya sampah di lokasi pengumpulan yaitu timbulnya pencemaran udara akibat aroma yang tidak sedap, banyak hewan seperti lalat, nyamuk, tikus dan yang lainnya yang membuat lingkungan sekitar semakin tidak nyaman. 
Dengan pertimbangan bahwa permasalahan tersebut harus segera diselesaikan, maka pengurus GKJW melalui penghubung yaitu seorang majelis gereja meminta kerjasama dengan Universitas Kristen Indonesia Jakarta dalam hal penanganan permasalah pengelolaan sampah yang sedang dihadapi. Pengajuan tersebut dibuktikan dengan adanya surat permintaan dari GKJW.

Universitas Kristen Indonesia yang merupakan perguruan tinggi yang menjalankan kewajiban Tri Dharma Perguruan Tinggi (salah satunya pengabdian kepada masyarakat) melalui Lembaga Penelitian dan Pengabdian kepada Masyarakat menyambut baik permintaan dari GKJW dengan mengirimkan tim yang berkompeten di bidang pengelolaan sampah ke Desa Tempursari, Kecamatan Tempursari, Kabupaten Lumajang, Provinsi Jawa Timur untuk mengadakan pelatihan dan pendampingan pengelolaan sampah di GKJW, Desa Tempursari.

Dari hasil analisis kebutuhan sesuai dengan permintaan GKJW Desa Tempursari, maka yang menjadi prioritas kegiatan pengabdian kepada masyarakat ini adalah pertama, pelatihan pengolahan sampah rumah tangga sehingga bisa dikonversi menjadi pupuk kompos. Kedua, pelatihan pengoperasian mesin pencacah sampah plastik sehingga bisa dikonversi menjadi biji plastik dan juga pengoperasian mesin pencacah sampah rumah tangga (organik) untuk selanjutnya diproses menjadi pupuk organik.

\section{Kelompok Sasaran}

Kelompok sasaran dari kegiatan pengabdian kepada masyarakat ini adalah para pengurus gereja yang bertugas dalam bidang pelayanan masyarakat terkhusus dalam pengelolaan sampah.

\section{Tujuan dan Manfaat}

Tujuan

Adapun yang menjadi tujuan dari kegiatan pengabdian kepada masyarakat ini adalah:

1. Meningkatkan pengetahuan mitra tentang pemilahan sampah

2. Meningkatkan motivasi mitra untuk mengelola dan mengolah sampah yang bersumber dari rumah tangga sehingga dapat mengurangi dampak pencemaran lingkungan

3. Diharapkan program perduli masyarakat dan lingkungan yang digagas oleh GKJW melalui pengeloaan sampah rumah tangga dari masyarakat Desa Tempursari dapat terlaksana dengan baik.

\section{Manfaat}

Masyarakat Desa Tempursari dapat mengelola sampah melalui koordinasi dengan GKJW. 


\section{METODE PELAKSANAAN}

Metode yang digunakan dalam kegiatan pengabdian kepada masyarakat ini adalah pelatihan yang diawali dengan pemaparan materi / teori, diskusi, selanjutnya praktik atau simulasi. Sedangkan tahapan pelaksanaan kegiatan PkM ini dimulai dari persiapan kegiatan oleh Tim UKI, pemetaan wilayah/lokasi, pelaksanaan pelatihan, monitoring dan evaluasi.

Adapun indikator keberhasilan kegiatan adalah sebagai berikut: mitra mengetahui tentang pemilahan sampah, mitra semakin termotivasi untuk mengelola dan mengolah sampah yang bersumber dari rumah tangga, mesin pencacah sampah organik (berupa sisa olahan dapur baik makanan, limbah sayuran, buah dan lainnya) dan mesin pencacah sampah plasti dapat beroperasi (mitra menguasai cara pengoperasian dan pengolahannya).

\section{HASIL DAN PEMBAHASAN}

Pelaksanaan kegiatan pengabdian kepada masyarakat diawali dengan observasi terlebih dahulu yang dilakukan pada tanggal 13 Juli 2017. Dari hasil observasi diperoleh data dan informasi tentang program yang sudah sempat berjalan sebelumnya mengenai pengolahan sampah, di mana pihak gereja GKJW pada tahun 2015 telah menerima hibah dari anggota jemaat yaitu dua unit mesin pencacah sampah (plastik dan sampah organik). Namun oleh karena keterbatasan sumber daya manusia, mesin tersebut belum pernah dioperasikan dan bahkan belum pernah diuji coba, dengan kata lain selama dua tahun mesin tersebut mangkrak dan tidak difungsikan. Akibat tidak bisa dioperasikannya mesin tersebut mengakibatkan terjasi penumpukan sampah di lokasi pengumpulan yang sudah ditentukan, yaitu di lahan belakang gedung gereja yang sudah dilengkapi dengan gudang penyimpanan sampah plastik dan lahan tanah yang sudah dilobangi untuk menampung sampah organik. Selanjutnya permasalahan tersebut didiskusikan oleh tim dan melakukan persiapan maksimal untuk tindak lanjut besok harinya.

Kegiatan berikutnya yaitu pada tanggal 14 Juli 2017, Tim berangkat ke lokasi yakni GKJW Tempursari. Di lokasi telah berkumpul semua pengurus pengolahan sampah dan juga beberapa warga masyarakat yang antusias dan ingin mengetahui secara langsung bagaimana tehnik pengolahan sampah yang dipaparkan oleh Tim. Sebelum ke lapangan, di dalam ruangan tim melakukan diskusi dan paparan tentang apa itu sebenarnya sampah, jenis dan sifat sampah, bagaimana pemilahan dan proses pengolahan, kerugian dari membiarkan sampah ada di sekitar kita dan juga keuntungan apabila kita mengolah sampah dengan baik dan benar.

Pada saat pemaparan, para peserta sangat antusias menyimak dan aktif berdiskusi, komunikasi dua arah 
berlangsung sekitar dua jam. Di akhir diskusi, tim melakukan evaluasi tentang pemahaman peserta melalui beberapa pertanyaan yang diajukan. Peserta sangat menyambut dengan baik dengan berlomba memberi jawaban, dan jawaban mereka sangat memuaskan. Untuk setiap peserta yang menjawab dengan sangat baik, diberikan tanda kasih oleh panitia berupa souvenir.

Setelah selesai sesi paparan dan diskusi, tim mengarahkan peserta untuk turun ke lokasi, yaitu gudang berisi timbunan sampah plastik, tempat penyimpanan mesin pencacah sampah plastik dan sampah organik. Kerjasama yang sangat baik dari peserta dapat dirasakan oleh tim PkM di mana semua perlengkapan yang tadinya diinfokan untuk mereka siapkan sudah disediakan. Tim langsung mulai dengan pengecekan mesin pencacah yang sama sekali belum pernah dioperasikan. Tim menemukan bahwa mesin sudah berkarat dan kabel sudah tidak berfungsi, selanjutnya dilakukan perbaikan oleh tim yang juga anggotanya sebagian adalah dosen tehnik mesin. Berselang beberapa waktu kemudian, mesin tersebut dapat dinyalakan dan dilanjutkan dengan uji coba penggilangan sampah plastik.

Pada awal proses operasi mesin, hasil penggilingan sampah plastik yang diperoleh sangat kasar dan sangat lambat keluar, kemudian tim mengamati dan mendapat ide untuk disiram dengan air bersih, dan hasilnya sangat luar biasa.
Sampah plastik hasil penggilingannya halus dan putih bersih. Semua peserta secara spontan bertepuk tangan dan bersorak karena hasil yang memuaskan. Berikut dokumentasi tim pada saat pengoperasian mesin pencacah sampah plastik.

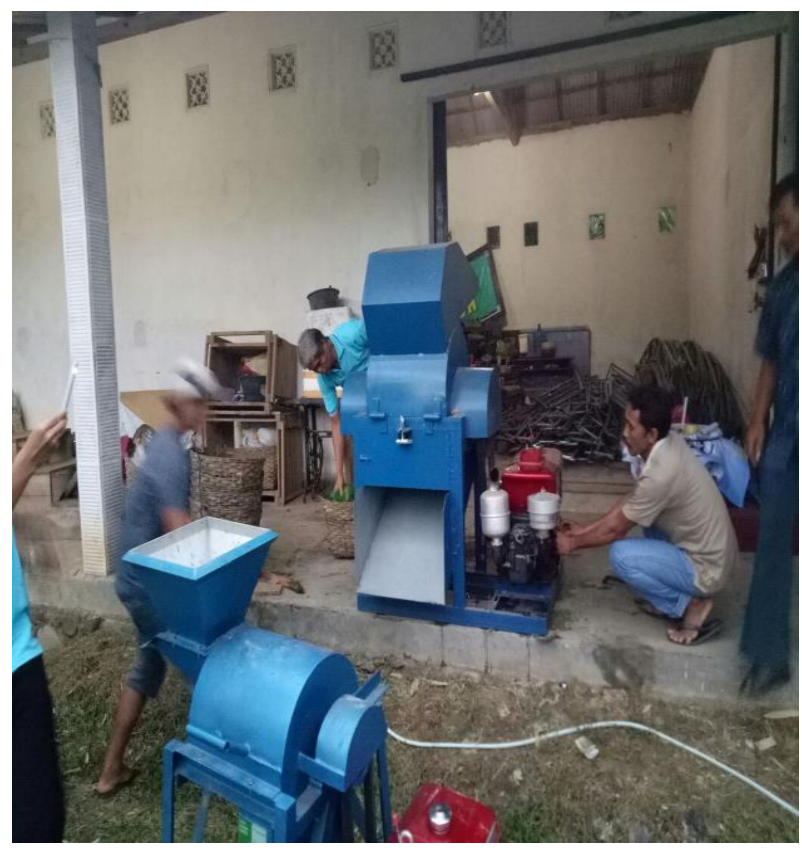

Gambar 1.

Tim sedang berusaha mengoperasikan mesin pencacah sampah anorganik yang selama ini menjadi keluhan Tim pengolah sampah desa Tempursari 


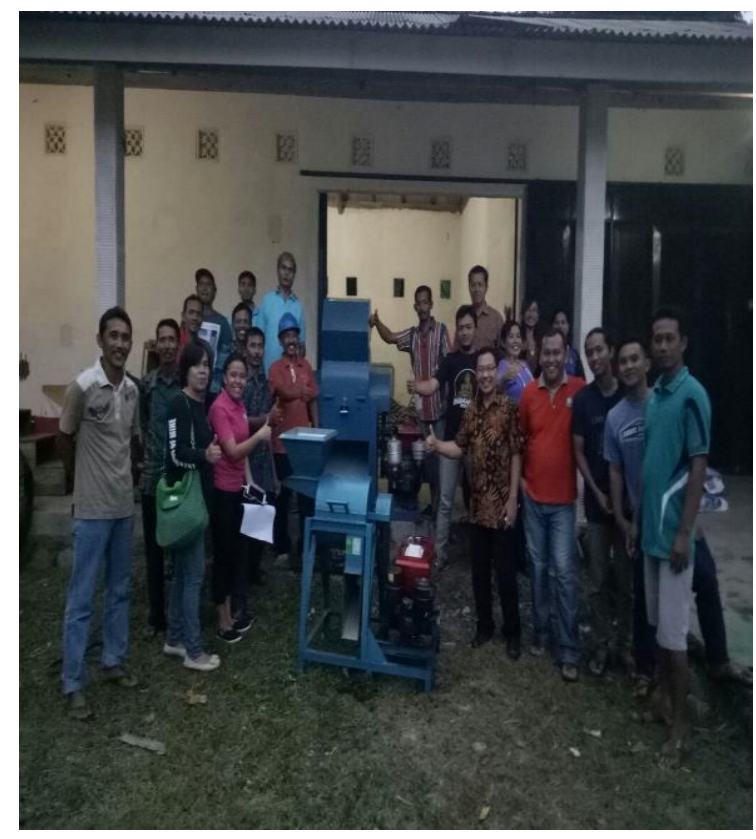

Gambar 2.

Tim dari UKI bersama Tim dari desa Tempursari dengan wajah bahagia dan bangga atas keberhasilan mengoperasikan mesin pencacah sampah organik dan anorganik yang selama ini dikeluhkan oleh Tim karena tidak dapat dioperasikan

Selain pengoperasian mesin pencacah sampah plastik, tim pengabdian juga melatih operator untuk mengoperasikan mesin pencacah sampah organik (sampah sisa pengolahan dapur seperti sisa nasi, ampas sayuran, buah-buahan) dan juga sampah dedaunan atau rerumputan yang bertebaran mengotori lingkungan sekitar rumah. Ukuran mesin pencacah sampah organik lebih kecil jika dibandingkan dengan mesin pencacah sampah plastik. Hasil yang diperoleh setelah melalui pengecekan dan pembenahan di beberapa bagian mesin, akhirnya mesin pencacah sampah organik juga dapat berfungsi dengan baik dengan hasil yang penggilingan cukup halus. Selanjutnya bahan yang sudah halus dimasukkan ke dalam komposter, lalu ditambahkan dengan dengan bahan untuk fermentasi (seperti EM4, air beras dan lainnya), kemudian diaduk sampai rata lalu ditutup. Hasil yang diharapkan diperoleh setelah dua sampai empat hari berikutnya, di mana diperoleh pupuk organik cair, yang secara perlahan dapat diambil dari bagian bawah tabung komposter yang sudah dilengkapi kran penutup/pembuka. Pupuk organik cair yang dihasilkan dimanfaatkan oleh masyarakat untuk menambah nutrisi tanaman yang ditanam di pekarangan rumah seperti sayuran, tanaman bunga dan lainnya.

\section{SIMPULAN}

Dari hasil kegiatan pengabdian kepada masyarakat di Desa Tempursari Kecamatan Tempursari, Kabupaten Lumajang, dapat disimpulkan bahwa kegiatan tersebut sangat sesuai dengan kebutuhan masyarakat, mengingat permasalahan sampah sudah menjadi permasalahan yang sudah cukup lala meresahkan masyarakat, terlebih lagi dengan tidak dapat beroperasinya mesin pencacah sampah plastik dan sampah organik yang tersedia di lingkungan gereja. Masyarakat sangat antusias, terlebih lagi para pengurus gereja yang secara khusus tergabung dalam tim pengelola sampah. Masyarakat menyatakan akan berkomitmen menerapkan dan melanjutkan apa yang sudah disosialisasikan melalui kegiatan 
pengabdian kepada masyarakat ini. Masyarakat berharap akan tetap dapat membina komunikasi dengan Universitas Kristen Indonesia untuk keberlanjutan pengolahan sampah seperti yang sudah diprogramkan oleh GKJW Tempursari.

\section{UCAPAN TERIMAKASIH}

Ucapan terimakasih kami sampaikan kepada:

1. Universitas Kristen Indonesia, sebagai afiliasi penulis dan sekaligus sebagai pemberi dana kegiatan pengabdian kepada masyarakat ini.

2. Pemda Kabupaten Lumajang yang turut mendukung perihal pemberian ijin mengadakan kegiatan pengabdian kepada masyarakat di Desa Tempursari dan memberikan penyambutan yang sangat ramah kepada Tim pada waktu pelaksanaan kegiatan

3. Para Pengurus Gereja Kristen Jawa Wetan (GKJW) yang telah berkoordinasi dengan sangat baik sehingga kegiatan pengabdian kepada masyarakat ini dapat berjalan dengan lancar dan memberikan hasil yang memuaskan.

4. Seluruh masyarakat Desa Tempursari, Kecamatan Tempursari, Kabupaten Lumajang Jawa Timur yang dengan antusias mengikuti kegiatan dengan penuh semangat.

\section{REFERENSI}

Damanhuri, E., \& Padmi, T. (2010). Pengelolaan sampah. Diktat Kuliah $T L$, 3104, 5-10.

Risman, Z., Setiawan, Y., \& Meicahayanti, I. (2018). Pengelolaan Sampah Pasar Di Kecamatan Loa Kulu Kabupaten Kutai Kartanegara Dengan Menggunakan Sistem Informasi Geografis (Sig). Jukung (Jurnal Teknik Lingkungan), 4 (1).

Herawati, D. A., \& Wibawa, A. A. (2010). Pengaruh pretreatment jerami padi pada produksi biogas dari jerami padi dan sampah sayur sawi hijau secara batch. Jurnal rekayasa proses, 4(1), 25-29.

Indriyanti, D. R., Banowati, E., \& Margunani, M. (2015). Pengolahan Limbah Organik Sampah Pasar Menjadi Kompos. Jurnal Abdimas, 19 (1).

Ruslinda, Y. (2014). Pengelolaan Sampah Kering Layak Jual Dengan Sistem Bank Sampah Di Kampus Universitas Andalas Padang. Jurnal Dampak, 11 (2), 96-109.

https://lumajangkab.go.id/profil/kectmpsr.p hp.,2019. 